\title{
PENGEMBANGAN ALPER SILABU PADA MATERI BILANGAN BULAT KELAS IV
}

\author{
Laurentius Pradipta Yudhautama1, Novisita Ratu ${ }^{2}$ \\ Universitas Kristen Satya Wacana Salatiga \\ Corresponding Author: laurentius.pradipta@gmail.com
}

\begin{abstract}
This study aims to teach the concept of addition and subtraction operations in elementary schools by using Alper Silabu. To develop Alper Silabu use the ADDIE model, which consists of five phases (Analysis, Design, Development, Implementation, and Evaluation). Alper Silabu has gone through tests of validity, practicality, and effectiveness. The results of Alper Silabu validity obtained $97.6 \%$, which means the media is valid. In practicality, the results are $93.3 \%$ total score, which means the media is practical. The results of the field trials obtained an N-Gain score of 0.81, which is in the high category. The N-Gain results show that Alper Silabu is effective to increase the understanding of students' concepts of addition and subtraction. Thus, Alper Silabu is valid, practices, and effective for teaching the math operation, especially addition and subtraction.
\end{abstract}

Keyword: Alper Silabu; addition and subtraction; ADDIE model

How to cite: Yudhautama, L., \& Ratu, N. (2019). Pengembangan Alper Silabu pada Materi Bilangan Bulat Kelas IV. Jurnal Review Pembelajaran Matematika, 4(1). JRPM (Jurnal Review Pembelajaran Matematika), 4(1), 72-84.

\section{PENDAHULUAN}

Sekolah dasar merupakan jenjang pendidikan yang paling awal, dimana peserta didik mengenal pengetahuan baru. Untari (2013) menyatakan sekolah dasar merupakan pondasi yang sangat bermanfaat dalam memasuki jenjang pendidikan yang lebih tinggi. Peran pengajar sangat penting agar informasi atau pengetahuan tersebut mudah diterima oleh peserta didik pada jenjang ini. Peran yang sangat diperlukan yaitu penanaman konsep, seperti yang diungkapkan Dindin (2008) bahwa ada salah satu kompetensi dasar yang mengarahkan peserta didik untuk mampu menggunakan konsep-konsep matematika dalam menyelesaikan masalah.

Penanaman konsep pada jenjang SD merupakan faktor terpenting bagi peserta didik seperti yang diungkapkan oleh Zulkardi (2003) bahwa mata pelajaran matematika menekankan pada konsep. Artinya dalam mempelajari matematika peserta didik harus memahami konsep matematika terlebih dahulu agar dapat menyelesaikan soal-soal dan mampu mengaplikasikan konsep tersebut dalam dunia nyata. Dengan berhasilnya penanaman konsep yang dilakukan pada jenjang ini, dapat membantu peserta didik untuk memudahkan menerima materi yang akan diberikan pada jenjang selanjutnya terlebih pada materi lanjutan.

Mata pelajaran matematika merupakan salah satu pelajaran yang ditakuti oleh peserta didik, hal tersebut disebabkan karena mereka mengalami kesulitan dalam hal menghafal 
maupun menyelesaikan masalah. Sirate (2012) mengatakan bahwa sebagian peserta didik mengakui bahwa matematika itu penting, namun sebagian dari mereka masih mengalami kesulitan dalam mempelajarinya. Hal tersebut dikarenakan matematika bersifat abstrak. Ermawati (2014) menambahkan karena sifat matematika yang abstrak tersebut pada akhirnya banyak peserta didik yang kurang tertarik terhadap matematika.

Menurut Marti (Rostina, 2016), guru juga mengalami kendala dalam mengajarkan matematika terkait sifatnya yang abstrak tersebut. Terutama gambaran konkret dari materi yang disampaikan, sehingga hal tersebut berakibat langsung kepada rendah dan tidak meratanya kualitas hasil yang dicapai oleh para peserta didik. Hikmah (2016) juga menambahkan bahwa peran guru dalam menyediakan dan memberikan pengalaman belajar yang bermakna sangat diperlukan. Kondisi semacam ini akan terus terjadi selama guru masih menganggap bahwa dirinya merupakan sumber belajar bagi peserta didik dan mengabaikan peran media pembelajaran. Seperti yang dinyatakan oleh Rohman, Mardiyana, dan Triyanto (2013) tentang cara mempelajari operasi bilangan bulat dimana guru masih menggunakan pembelajaran konvensional serta kurang dalam penggunaan alat peraga yang ada di lingkungan sekitar dalam menjelaskan operasi bilangan bulat. Selain itu, guru juga kurang mengaitkan pembelajaran operasi bilangan bulat dengan bentuk konkret atau nyata dalam kehidupan sehari-hari. Padahal Kustianti (2014) menjelaskan bahwa salah satu upaya untuk mengatasi segala bentuk kesulitan yang timbul dalam proses pembelajaran terutama menyangkut daya serap peserta didik adalah penggunaan media pembelajaran. Konsep dalam matematika tidak semuanya dapat dijelaskan secara teoritis, matematika membutuhkan alat pendukung untuk menjelaskan materi yang tidak dapat dijelaskan secara teori salah satunya menggunakan media pembelajaran

Media pembelajaran matematika memiliki beragam jenis. Menurut Sudjana dan Rivai (2010), media pembelajaran dibagi menjadi 3 karakteristik yaitu media dua dimensi, media tiga dimensi dan media proyeksi. Namun, penggunaan media tiga dimensi memiliki dampak lebih baik terhadap pemahaman peserta didik akan pembelajaran. Hal tersebut diungkapkan oleh Sudjana dan Rivai (2010) bahwa pembelajaran akan lebih menarik perhatian peserta didik sehingga dapat menumbuhkan motivasi belajar, bahan pembelajaran akan lebih jelas maknanya sehingga dapat lebih dipahami oleh peserta didik, dan memungkinkan peserta didik menguasai materi pembelajaran dengan lebih baik, metode pembelajaran akan lebih bervariasi, tidak semata-mata komunikasi verbal melalui penuturan kata-kata oleh guru, dan peserta didik lebih banyak melakukan kegiatan belajar media pembelajaran. Kania (2018) 
menambahkan pembelajaran matematika dengan menggunakan benda manipulatif lebih baik dari pada pemahaman konsep pecahan peserta didik yang mendapatkan pembelajaran matematika dengan pembelajaran konvensional. Dengan begitu, media pembelajaran tiga dimensi memiliki nilai kelebihan tersendiri.

Media pembelajaran tiga dimensi yaitu dalam bentuk model seperti model padat, model penampang, model susun, model kerja, mock up, diorama, dan lain-lain (Sudjana \& Rivai, 2010). Begitupun dengan alat peraga yang merupakan bagian dari media tiga dimensi. Menurut Pramudjono (1995) alat peraga adalah benda konkret yang dibuat, dihimpun, atau disusun secara sengaja yang digunakan untuk membantu menanamkan atau mengembangkan konsep matematika. Sedangkan Prastowo (2017) mengatakan alat peraga adalah media yang memiliki ciri dan/atau bentuk dari konsep materi ajar yang digunakan untuk memperagakan materi tersebut sehingga materi pembelajaran lebih mudah dipahami oleh peserta didik. Dengan dibentuknya konsep dasar yang sempurna, maka peserta didik akan mudah ketika materi itu berlanjut. Salah satu materi pelajaran matematika yang memerlukan pemahaman konsep adalah bilangan bulat.

Bilangan bulat merupakan salah satu materi yang dipakai dalam kehidupan sehari-hari. Bilangan bulat adalah materi yang pertama kali diajarkan pada kelas IV (Permendikbud, 2016). Setyaningsih (2014) menjelaskan bahwa bilangan bulat meliputi bilangan bulat negatif, nol, dan bilangan bulat positif. Operasi hitung bilangan bulat meliputi penjumlahan, pengurangan, perkalian, dan pembagian. Namun, pada kelas IV operasi hitung yang diajarkan meliputi pengurangan dan penjumlahan saja. Meskipun hanya meliputi pengurangan dan penjumlahan, peserta didik masih sering mengalami kebingungan ketika peserta didik dihadapkan pada suatu permasalahan. Hal tersebut mengakibatkan rendahnya hasil belajar peserta didik. Menurut Eliana (2016), hasil belajar matematika pada materi operasi penjumlahan bilangan bulat pada peserta didik kelas IV sangat rendah. Banyak peserta didik yang belum mampu menentukan hasil akhir dengan benar. Mereka hanya menebak hasil akhir bertanda positif atau negatif. Hal tersebut dikarenakan strategi pembelajaran yang diterapkan kurang menarik minat peserta didik.

Ilma (2014) mengatakan bahwa sebagian guru mengalami kendala dalam pembelajaran matematika khususnya bilangan bulat, dikarenakan guru tidak mampu mengajarkan operasi bilangan bulat secara menarik. Pembelajaran matematika menjadi mata pelajaran yang sangat serius. Strategi pembelajaran yang diterapkan cenderung membuat peserta didik merasa bosan dan malas untuk memperhatikan proses pembelajaran. Dengan menggunakan media 
pembelajaran, diharapkan peserta didik dapat meningkatkan motivasi atau hasil belajar peserta didik.

Alat peraga bilangan bulat sudah banyak dikembangkan baik secara konsep maupun evaluasi. Beberapa alat peraga yang telah dikembangkan yaitu garis bilangan, manik-manik, ular tangga, domino, dan masih banyak lagi. Alat peraga (Alper) Silabu merupakan media pembelajaran baru pada operasi bilangan bulat yang diharapkan dapat menarik perhatian peserta didik melalui penggunaan teknologi. Pembuatan Alper Silabu (alat peraga garis bilangan) merupakan pengembangan dari garis bilangan. Konsep penggunaan silabu tidak berbeda dari garis bilangan pada umumnya. Alper Silabu disajikan sesuai dengan umur siswa kelas IV, dimana terdapat banyak warna dan lampu-lampu sehingga diharapkan alat peraga silabu dapat meningkatan nilai peserta didik pada materi bilangan bulat khususnya pada operasi penjumlahan dan pengurangannya. Dengan demikian penelitian ini berjudul Pengembangan Alper Silabu pada Materi Bilangan Bulat Kelas IV. Tujuan penelitian ini adalah untuk mengetahui proses pengembangan media pembalajaran Alper Silabu, kevalidan media Alper Silabu, serta respon dan hasil belajar siswa setelah penerapan media Alper Silabu dalam pembelajaran materi bilangan bulat.

\section{METODE PENELITIAN}

Penelitian ini menggunakan metode metode penelitian dan pengembangan (R\&D). Penelitian ini diawali dengan melakukan research dan setelah itu melakukan kegiatan development. Tujuan dilakukan kegiatan research adalah untuk mendapatkan berbagai kebutuhan peserta didik kelas IV Ungaran pada materi bilangan bulat. Kemudian, pada tahap development dilakukan dengan tujuan membuat produk media pembelajaran matematika berupa alat peraga silabu.

Tujuan dari research and development adalah untuk menghasilkan produk baru atau perbaikan produk lama yang berupa alat peraga silabu. Sehingga diharapkan pembelajaran operasi hitung pada bilangan bulat menjadi lebih menarik, tidak monoton, dan memberikan pengaruh bagi peserta didik sehingga hasil belajarnya meningkat.

Dengan metode R\&D, maka dipilih model pengembangan ADDIE yang dikembangkan oleh Robert Maribe Bransch (Pribadi, 2009). Model Pembelajaran ADDIE meliputi berbagai tahapan yaitu analysis, design, development, implementation, dan evaluation. Tahapan-tahapan model pembelajaran ADDIE mempunyai hubungan di setiap tahapnya sehingga semua tahapan harus dilakukan secara urut. Adapun rancangan model 
pengembangan ADDIE disajikan pada Gambar 1 berikut:

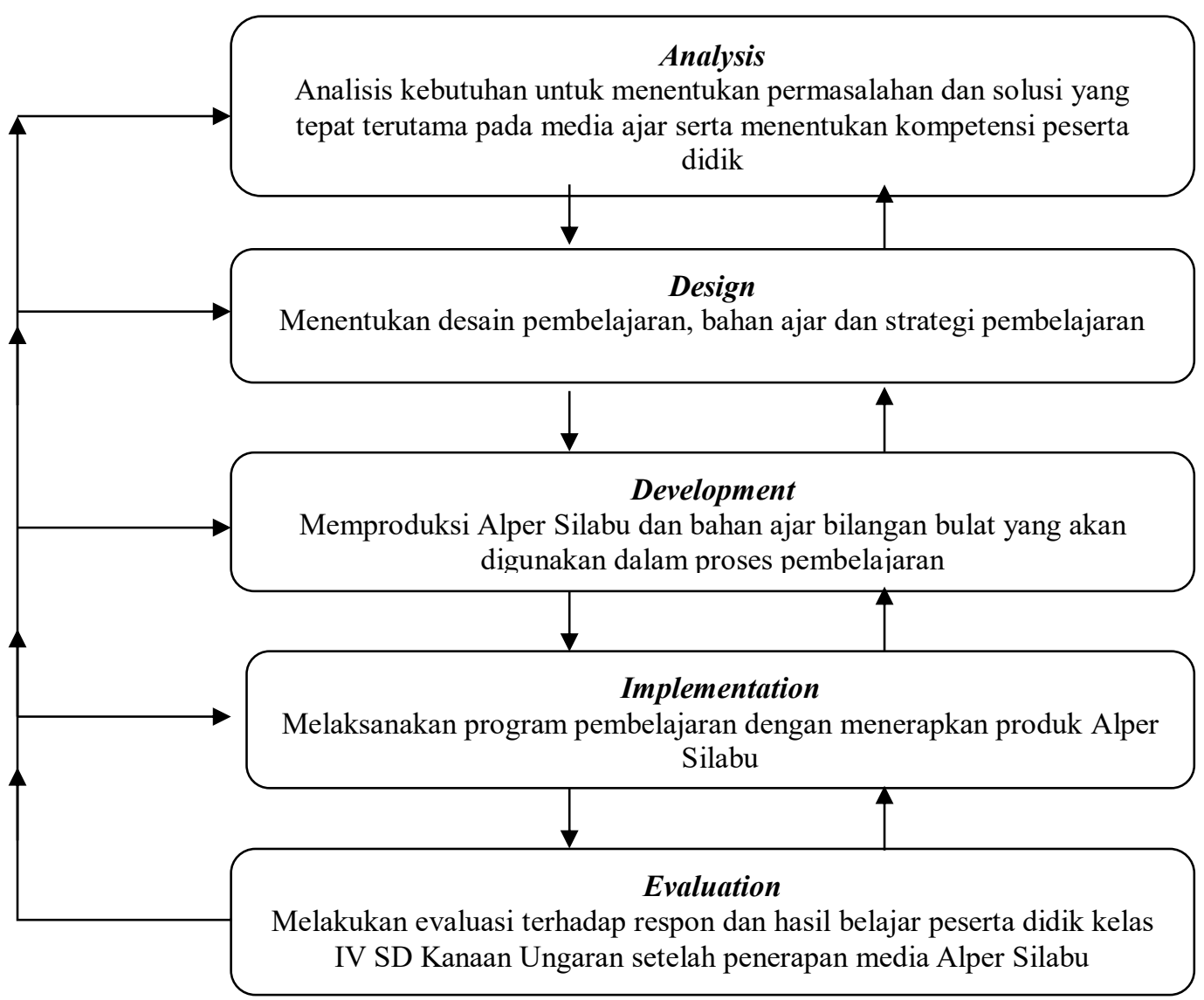

Gambar 1. Rancangan Model ADDIE

Teknik pengumpulan data yang digunakan adalah melalui angket dan lembar tes. Metode angket digunakan untuk mendapatkan data tentang kevalidan media Alper Silabu dan respon siswa setelah menggunakan media tersebut, sedangkan metode tes digunakan untuk mendapatkan data tentang hasil belajar siswa. Skala penilaian angket dikategorikan menjadi 5 kriteria yaitu: 1) sangat kurang 2) kurang 3) cukup 4) baik dan 5) sangat baik. Dari hasil perolehan data angket tersebut akan dilakukan pengolahan data dengan menggunakan rumus

$$
\text { Persentase penilaian: } \frac{\text { skor hasil penelitian }}{\text { skor maksimal }} \times 100 \%
$$

Hasil persentase kemudian akan dikategorikan menurut kriteria penilaian pada Tabel 1.

Tabel 1. Kriteria Penilaian

\begin{tabular}{ccc}
\hline No & Interval & Kategori Kualitatif \\
\hline 1 & $85 \% \leq$ skor $\leq 100 \%$ & Sangat baik \\
2 & $69 \% \leq$ skor $<85 \%$ & Baik \\
3 & $53 \% \leq$ skor $<69 \%$ & Cukup \\
4 & $37 \% \leq$ skor $<53 \%$ & Kurang \\
5 & $20 \% \leq$ skor $<37 \%$ & Sangat kurang \\
\hline
\end{tabular}

Metode tes dilakukan sebelum dan sesudah penggunaan media pembelajaran menggunakan instrumen pretest dan posttest. Media Pembelajaran akan dikatakan memenuhi 
persyaratan jika memperoleh minimal 69\% atau pada kategori baik. Jika persyaratan sudah terpenuhi maka uji coba media dapat dilakukan. Hasil dari pretest dan posttest peserta didik yang telah didapatkan akan dianalisis terhadap hasil belajar menggunakan rumus N-Gain untuk menentukan peningkatan yang terjadi setelah dilakukan penerapan media Alper Silabu, dengan rumus sebagai berikut:

$$
N-\text { Gain }=\frac{\text { skor posttest }- \text { skor pretest }}{\text { skor maksimum }- \text { skor pretest }}
$$

Setelah mendapatkan hasil skor N-Gain, akan ditentukan tingkat kategori menurut klasifikasi N-Gain pada Tabel 2

Tabel 2. Klasifikasi N-Gain

\begin{tabular}{cc}
\hline Skor N-Gain & Kategori \\
\hline$G \geq 0,70$ & Kategori Tinggi \\
$0,30 \geq G>0,70$ & Kategori Sedang \\
$G>0,30$ & Kategori Rendah \\
\hline
\end{tabular}

Skor N-Gain yang didapat merupakan bentuk alat ukur untuk mencari tingkat keefektifan media yang digunakan. Semakin tinggi kategori yang didapatkan maka semakin efektif media pembelajaran yang dibuat.

\section{HASIL DAN PEMBAHASAN}

Pendekatan Research and Development dan Model Pengembangan ADDIE, merupakan pendekatan dan model yang digunakan pada penelitian ini. Penelitian dan pengembangan media Alper Silabu yang digunakan sebagai media pembelajaran matematika pada materi bilangan bulat diterapkan pada kelas IV di SD Kanaan Ungaran. Instrumen pada penelitian ini meliputi angket validasi instrumen, pendapat peserta didik mengenai Alper Silabu dan juga soal-soal latihan untuk mengukur hasil belajar peserta didik sebelum dan sesudah penderapan media Alper Silabu. Dari hasil yang sudah didapatkan dilakukan analisis kuantitatif dan kualitatif. Hasil penelitian akan dijelaskan secara rinci sebagai berikut:

\section{Analyze (Analisis)}

Pada tahap ini dianalisis peserta didik yang masih kesulitan terhadap bilangan bulat positif dan negatif, khususnya pada operasi penjumlahan dan pengurangan bilangan bulat. Bilangan bulat yang akan diajarkan pada peserta didik kelas IV mempunyai 2 kompetensi dasar yaitu pada KD 3.2 (menjelaskan dan melakukan operasi hitung bilangan bulat dan pecahan dan memanfaatkan berbagai sifat operasi) dan KD 4.2 (menyelesaikan masalah yang berkaitan dengan operasi hitung bilangan bulat dan pecahan). 


\section{Design (Desain)}

Berdasarkan hasil dari tahap analysis dan kebutuhan alat bantu pembelajaran untuk menyampaikan konsep operasi penjumlahan dan pengurangan bilangan bulat, maka didesain media pembelajaran berupa alat peraga dengan tujuan untuk membantu guru menjelaskan konsep operasi bilangan bulat yang mudah dimengerti oleh peserta didik. Alper Silabu sendiri dibuat dengan menggunakan rangkaian lampu LED dengan warna hijau dan merah yang disusun pada 2 buah PCB. Masing-masing PCB memiliki ukuran panjang $22 \mathrm{~cm}$ dan lebar 10 cm. PCB pertama berguna sebagai tempat rangkaian lampu LED, sedangkan PCB kedua sebagai tempat rangkaian saklar. Gambar 2 adalah desain Alper Silabu yang dibuat dari bahan kayu triplek dengan ketebalan $0.5 \mathrm{~cm}$, panjang 41,7 cm, lebar 25,4 cm, tinggi 7,7 cm. Sedangkan Gambar 3 merupakan rangkaian lampu LED dan saklar pada PCB yang digunakan sebagai mesin atau otak media pembelajaran tersebut.

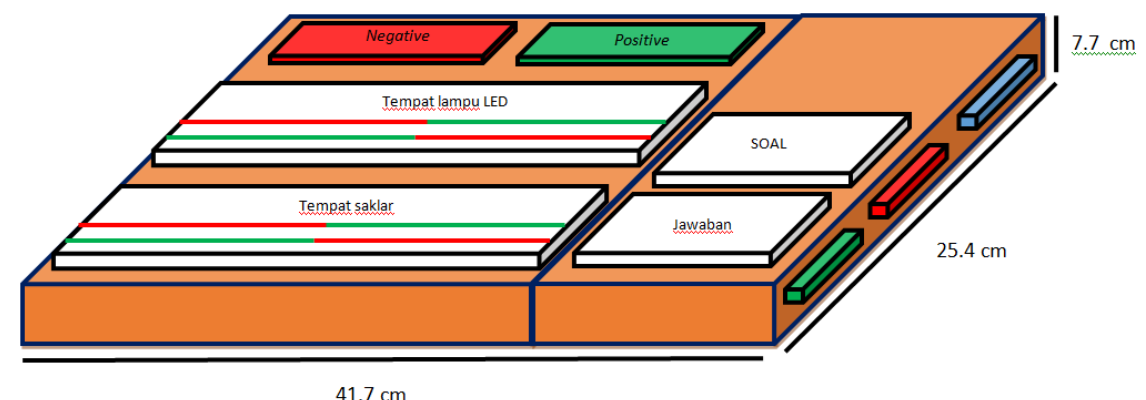

Gambar 2. Desain ALPER SILABU

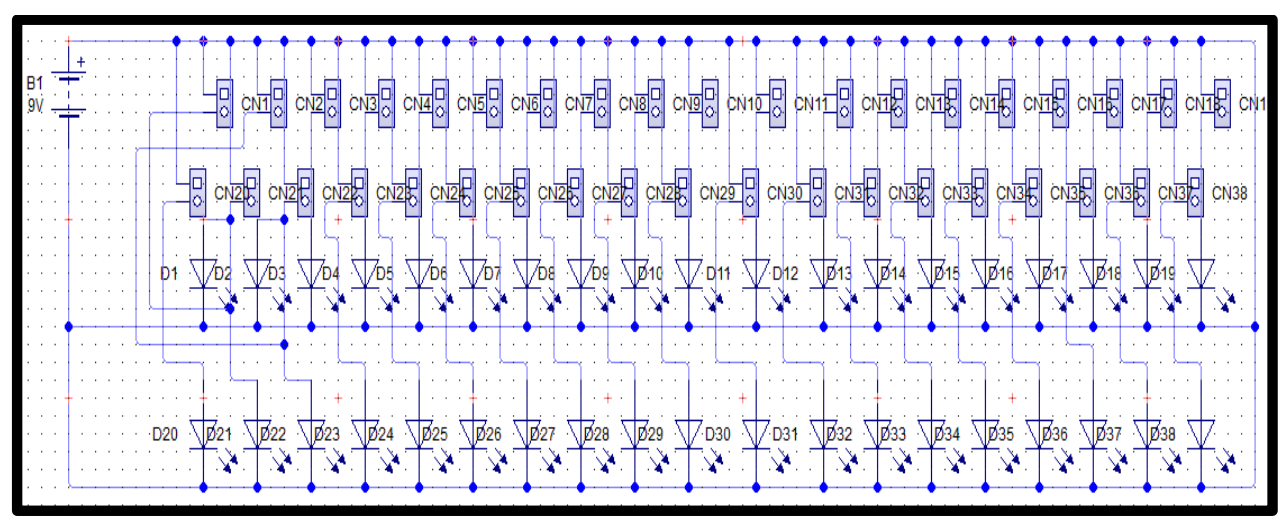

Gambar 3 . Desain Rangkaian Lampu LED dan Saklar pada PCB

\section{Development (Pengembangan)}

Pada tahap ini akan dilakukan pembuatan media pembelajaran alat peraga Silabu yang digunakan untuk mengajarkan operasi bilangan bulat khususnya penjumlahan dan pengurangan. Pengembangan yang dilakukan meliputi berbagai tahapan yaitu penyusunan desain media pembelajaran berdasarkan berbagai masukan. Kemudian, dilakukan pembuatan media dengan berbagai pertimbangan dan dilanjutkan dengan pengecekan berbagai faktor 
untuk meminimalisir kesalahan yang akan terjadi. Adapun hasil tahapan pengembangan Alper Silabu sebagai berikut:

Pertama, pembuatan Alper Silabu. Alper Silabu merupakan alat peraga yang didesain untuk memudahkan peserta didik memahami penjumlahan dan pengurangan operasi bilangan bulat dengan cara yang lebih menarik. Alper Silabu dibuat dari susunan beberapa lampu LED dengan warna merah dan hijau. Warna merah melambangkan bilangan bulat negatif dan warna hijau melambangkan bilangan bulat positif. Pemilihan warna lampu LED berdasarkan warna lampu traffic light ketika warna merah kendaraan akan berhenti dibelakang garis dan pada saat lampu hijau kendaraan akan melanjutkan perjalanannya.

Alper Silabu tersusun dari lampu-lampu LED yang sejajar. Total lampu keseluruhan adalah 40 buah, dimana lampu tersebut dibagi menjadi dua baris. Tiap-tiap baris berisi 20 lampu LED yang terdiri atas warna hijau dan warna merah dengan jumlah yang sama dan memungkinkan untuk menyala semuanya. Alper Silabu menggunakan kabel USB sebagai pengantar tenaga listriknya, sehingga dapat digunakan dimanapun dan kapanpun. Power bank dapat digunakan sebagai sumber energi ketika digunakan di luar ruangan, sedangkan ketika di dalam ruangan dapat menggunakan charger handphone. Terdapat 40 buah saklar sesuai dengan jumlah lampu LED yang ada, sehingga 1 lampu memiliki 1 buah saklar. Media pembelajaran Alper Silabu disusun dan dibuat berdasarkan materi bilangan bulat pada kelas IV.
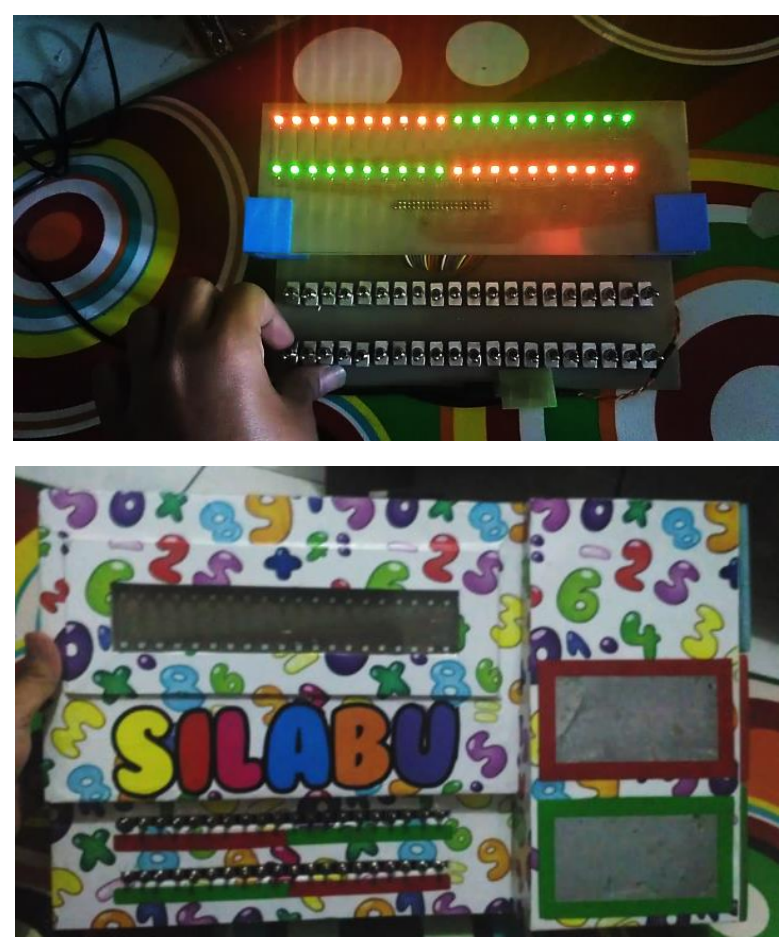

Gambar 4. Media Pembelajaran Alper Silabu 
Kedua, tahap uji produk Alper Silabu. Media Alper Silabu yang telah dibuat akan divalidasi oleh ahli media dan ahli materi. Validasi dilakukan untuk mendapatkan masukan berupa saran dan kritik yang digunakan untuk memperbaiki ALPER SILABU jika masih terdapat kekurangan. Masukan yang diberikan validator antara lain: 1) lampu indikator dipastikan tidak mati; 2) adanya dua lampu indikator yang mati. Setelah mendapatkan masukan, maka media direvisi sesuai dengan saran dan kritik dari validator, sebagaimana disajikan pada Tabel 3 .

Tabel 3. Saran, Kritik, dan Tindak Lanjut

\begin{tabular}{cc}
\hline Saran dan Kritik & Tindak Lanjut \\
\hline Lampu indikator dipastikan tidak mati & $\begin{array}{c}\text { Perlunya pengecekan ulang sebelum } \\
\text { media Alper Silabu digunakan }\end{array}$ \\
Adanya 2 lampu indikator yang mati & Melakukan pergantian lampu indikator yang mati \\
\hline
\end{tabular}

Berdasarkan saran dan kritik yang diberikan oleh validator, maka dilakukan tahap perbaikan sesuai dengan masukan kedua ahli. Setelah dilakukan perbaikan maka ALPER SILABU sudah dapat digunakan dalam penelitian.

\section{Implementation (Implementasi)}

Tahap implementasi dilaksanakan di kelas IV SD Kanaan Ungaran dengan menggunakan media pembelajaran Alper Silabu. Pengaruh penerapan media Alper Silabu yaitu berdasarkan hasil pretest, posttest, dan respon siswa terhadap Alper Silabu. Pretest dilakukan untuk mengetahui hasil belajar peserta didik sebelum penerapan media Alper Silabu sebagai alat bantu belajar dengan jumlah soal 10 butir. Hasil pretest kemudian dianalisis. Hasil dari pretest tersebut merupakan dasar dari pengukuran hasil belajar peserta didik. Setelah itu, proses pembelajaran menggunakan Alper Silabu akan dilakukan sebanyak tiga kali pertemuan. Selama proses pembelajaran, peserta didik diminta untuk menyelesaikan soal dengan menggunakan bantuan media Alper Silabu. Soal posttest dengan jumlah dan bobot soal yang sama dengan soal pretest. Kemudian, bedasarkan hasil posttest yang didapat akan dibandingan dengan hasil pretest. Hal tersebut dilakukan untuk mengetahui seberapa besar dampak yang diberikan Alper Silabu terhadap hasil belajar peserta didik. Pada tahap akhir, diberikan lembar angket respon siswa terhadap Alper Silabu. Hal tersebut bertujuan agar peserta didik dapat memberikan tanggapannya tentang Alper Silabu yang telah digunakan sebagai alat bantu belajar.

\section{Evaluation (Evaluasi)}

Berdasarkan hasil evaluasi diharapkan dapat dijadikan sebagai perbaikan untuk Alper Silabu pada penelitian selanjutnya. Hasil evaluasi antara lain: 1) Analisis data validasi, 
berdasarkan dari hasil validasi yang dilakukan, Alper Silabu memperoleh hasil 97,6\% yang dapat dikategorikan sangat baik. Dengan tingkat hasil 97,6\% menunjukkan bahwa desain media tersebut menarik, mudah digunakan, dan dapat meningkatkan minat belajar peserta didik; 2) Analisis data kepraktisan, berdasarkan hasil analisis lembar kepraktisan Alper Silabu, guru SD Kanaan Ungaran sekaligus pengguna media pembelajaran memberikan hasil sebesar 93,3\% yang dapat dikategorikan sangat baik. Hasil tersebut menunjukkan bahwa Alper Silabu merupakan media yang sesuai dengan kebutuhan pembelajaran di kelas, prosedur penggunaan media jelas dan mudah dipahami, media dapat digunakan berulang kali, media mudah dibawa dan dipindahkan, bentuk dan ukuran media sesuai, dan media dapat digunakan di dalam maupun di luar kelas. Sehingga dapat disimpulkan bahwa Alper Silabu praktis digunakan sebagai alat bantu belajar peserta didik; 3) Analisis data keefektifan, dimana keefektifan Alper Silabu dapat dilihat dari hasil belajar setelah penerapan media dan lembar respon siswa. Hasil belajar peserta didik sebelum menggunakan media (pretest) dan hasil belajar peserta didik setelah menggunakan media (posttest) peserta didik kelas IV SD Kanaan disajikan pada Tabel 4.

Tabel 4. Data Nilai Pretest dan Posttest

\begin{tabular}{ccccc}
\hline $\begin{array}{c}\text { Sebelum menggunakan Media } \\
\text { (pretest) }\end{array}$ & \multicolumn{2}{c}{$\begin{array}{c}\text { Setelah menggunakan media } \\
\text { (posttest) }\end{array}$} & Skor Maksimum \\
\hline Skor & Rata-rata & Skor & Rata-rata & 1200 \\
340 & 28,33 & 1040 & 86,66 & \\
\hline
\end{tabular}

Data yang telah didapatkan kemudian dianalisis, analisis dilakukan berdasarkan dari nilai sebelum menggunakan media dan nilai setelah menggunakan media. Kemudian dilanjutkan dengan analisis signifikansinya berdasarkan peningkatan yang terjadi. Analisis dilakukan dengan menggunakan rumus N-Gain sebagai berikut:

$$
\begin{aligned}
N-\text { Gain } & =\frac{\text { skor posttest }- \text { skor pretest }}{\text { skor maksimum }- \text { skor pretest }} \\
& N-\text { Gain }=\frac{1040-340}{1200-340} \\
& N-\text { Gain }=0,81
\end{aligned}
$$

Berdasarkan hasil perhitungan yang telah dilakukan, diperoleh nilai N-Gain sebesar 0,81 yang dapat dikategorikan tinggi menurut klasifikasi N-Gain. Hal tersebut menunjukkan bahwa dengan menggunakan alat bantu berupa Alper Silabu dapat meningkatkan hasil belajar peserta didik dan Alper Silabu efektif digunakan dalam pembelajaran. Grafik hasil sebelum menggunakan media dan sesudah menggunakan media dapat dilihat pada Gambar 5. 


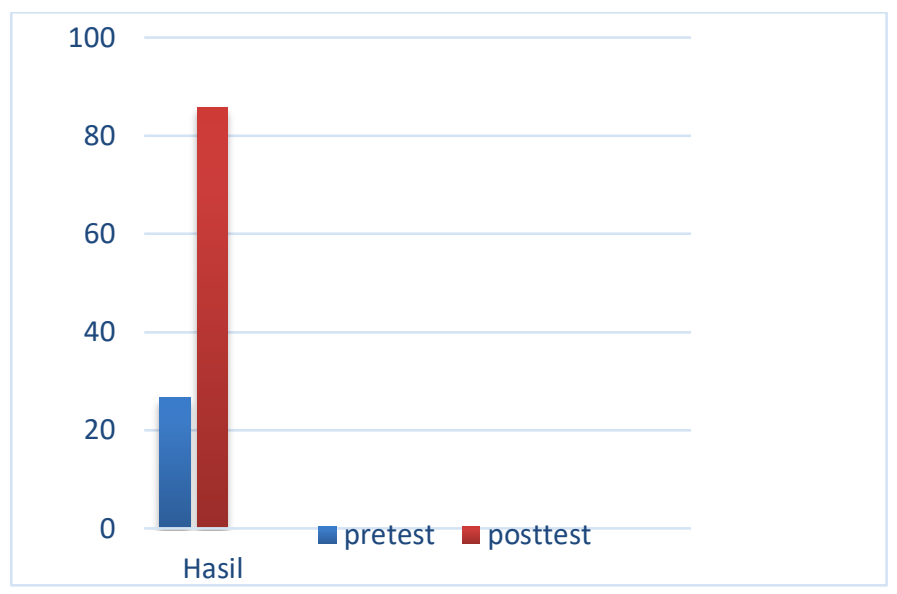

Gambar 5. Rata-Rata Peningkatan Hasil Belajar Peserta didik

Berdasarkan hasil analisis respon siswa didapatkan bahwa Alper Silabu membantu peserta didik dalam belajar operasi penjumlahan dan pengurangan pada bilangan bulat. Desain tampilan yang menarik dan warna lampu membuat pembelajaran tidak terasa membosankan sehingga dapat membuat peserta didik fokus terhadap Alper Silabu. Penyampaian konsep operasi penjumlahan dan pengurangan pada bilangan bulat dapat berjalan secara optimal sehingga materi yang disampaikan dapat diterima oleh peserta didik dengan mudah karena adanya media pembelajaran Alper Silabu. Selain itu, lembar panduan petunjuk penggunaannya mudah dipahami dan membuat peserta didik semangat untuk belajar. Dari hasil keseluruhan menunjukkan bahwa Alper Silabu berguna bagi peserta didik kelas IV SD Kanaan Ungaran. Hal tersebut berdasarkan pada 10 dari 12 siswa memberikan respon positif, sehingga diperoleh persentase respon siswa sebesar 83,33\% dan meningkatnya hasil belajar peserta didik dengan penerapan media pembelajaran Alper Silabu.

\section{SIMPULAN DAN SARAN}

Berdasarkan dari hasil dan pembahasan yang telah dijelaskan sebelumnya, maka diperoleh beberapa kesimpulan. Pertama, produk yang dihasilkan pada penelitian dan pengembangan media pembelajaran Alper Silabu dilakukan proses validasi sebelum digunakan sebagai pengambilan data yang akan dilaksanakan di SD Kanaan Ungaran. Dari proses validasi yang dilakukan, mendapatkan hasil kevalidan media dengan persentase $97,6 \%$. Kedua, penggunaan Alper Silabu menunjukkan pengaruh yang bagus terhadap peserta didik kelas IV SD Kanaan Ungaran. Pengaruh media pembelajaran Alper Silabu terlihat pada saat penjelasan konsep operasi penjumlahan dan pengurangan bilangan bulat yang dapat meningkatkan hasil belajar, dengan begitu Alper Silabu efektif digunakan. 
Tingkat persentase hasil belajar setelah menggunakan media (posttest) dibandingan dengan nilai sebelum menggunakan media (pretest). Setelah dilakukan proses perbandingan kemudian diambil kesimpulan yaitu Alper Silabu memiliki pengaruh yang bagus sebagai alat bantu belajar peserta didik SD kelas IV SD Kanaan Ungaran dikarenakan terdapat peningkatan hasil belajar siswa sebesar 58,33 dari rata-rata 28,33 menjadi 86,66. Selain itu, peserta didik memberikan respon positif terhadap Alper Silabu. Dengan demikian, kesimpulan yang diperoleh berdasarkan hasil tersebut yaitu Alper Silabu memiliki pengaruh yang efektif digunakan oleh peserta didik kelas IV.

Saran bagi yang pengembangan media ini lebih lanjut antara lain, yaitu media pembelajaran Alper Silabu dapat disempurnakan, khususnya dibuat dari bahan yang mudah didapat dan harga yang lebih terjangkau, serta perlu peningakatan dari segi perakitan lampu, saklar, penampilan, dan packing media.

\section{DAFTAR PUSTAKA}

Dindin, A. M. L. (2008). Strategi pembelajaran pemecahan masalah di sekolah dasar. Jurnal Pendidikan Dasar, $10 . \quad$ Retrived from http:// file.upi.edu/Direktori/JURNAL/PENDIDIKAN_DASAR/Nomor_10Oktober_2008/Strategi_Pembelajaran_Pemecahan_Masalah_di_Sekolah_Dasar.pdf.

Eliana, N. (2016). Peningkatan Hasil Belajar Matematika Materi Operasi Penjumlahan Bilangan Bulat Melalui Permainan Lompat Henti. Jurnal Pendidikan Dasar, 7(1), 90-99. https://doi.org/10.21009/JPD.071.08.

Ermawati, S. E. (2014). Peningkatan Menghitung Operasi Bilangan Bulat dengan Metode Ekspository Berbantuan Media Garis Bilangan. Didaktinum: Jurnal Penelitian Tindakan Kelas, 17(2), 1-6.

Hikmah, N. (2016). Peningkatan hasil belajar matematika tentang penjumlahan dan pengurangan bilangan bulat melalui alat peraga mistar bilangan pada peserta didik kelas IV SDN 005 Samarinda Ulu. Jurnal Pendas Mahaka, 1(1), 80-85. Retrieved from https://jurnal.fkip-uwgm.ac.id/index.php/pendasmahakam/article/view/46/16

Ilma, R. (2011). Implementasi Alat Peraga Bilangan Bulat Bagi Guru Sekolah Dasar (SD) SeKecamatan Ilir Barat 1 Palembang. Jurnal Pendidikan Matematika, 5(1), 73-79. DOI: https://doi.org/10.22342/jpm.5.1.823.

Kania, N. (2018). Alat Peraga untuk Memahami Konsep Pecahan. Jurnal THEOREMS (The Original Research of Mathematics), 2(2), 1-12. Retrieved from https://jurnal.unma.ac.id/index.php/th/article/view/699. 
Kementerian Pendidikan dan Kebudayaan. (2016). Permendikbud Nomor 24 tentang Kompetensi Inti Dan Kompetensi Dasar Pelajaran pada Kurikulum 2013 Pada Pendidikan Dasar dan Pendidikan Menengah. Jakarta: Kemendikbud.

Kustianti, D. (2014). Meningkatkan Hasil Belajar Peserta Didik Kelas IV SDN 2 Patukuki pada Pokok Bahasan Penjumlahan dan Pengurangan Bilangan Bulat Melalui Pembelajaran Menggunakan Media Kartu. Jurnal Kreatif Online, 2(2), 171-181. Retrieved from http://jurnal.untad.ac.id/jurnal/index.php/JKTO/article/view/2848

Prastowo, A. (2017). Menyusun Pelaksanaan Pembelajaran (RPP) Tematik Terpadu. Jakarta: Kencana

Pribadi, B.A. (2009). Model Desain Sistem Pembelajaran. Jakarta: PT Dian Rakyat.

Rohman, N., Mardiyana, \& Triyanto. (2013). Eksperimen Pendekatan Pembelajaran Pendidikan Matematika Realistik dan Problem Based Learning pada Operasi Bilangan Bulat Ditinjau dari Gaya Belajar Siswa. Jurnal Pendidikan Matematika, 1(2), 153-166. Retrieved from https://jurnal.fkip.uns.ac.id/index.php/s2math/article/view/3491.

Setyaningsih, N. A. (2014). penggunaan media mistar bilangan untuk meningkatkan hasil belajar penjumlahan bilangan bulat peserta didik sekolah dasar. Jurnal Penelitian Pendidikan Guru Sekolah Dasar, 2(2), 1-14. Retrieved from http://jurnalmahasiswa.unesa.ac.id/index.php/jurnal-penelitianpgsd/article/view/10584.

Sirate, F. S. (2012). Implementasi Etnomatematika dalam Pembelajaran Matematika pada Jenjang Pendidikan Sekolah Dasar. Lentera Pendidikan: Jurnal Ilmu Tarbiyah dan Keguruan, 15(1), 41-54. DOI: DOI: https://doi.org/10.24252/lp.2012v15n1a4.

Sudjana, N. \& Rivai, A. (2010). Media Pengajaran. Bandung: Sinar Baru Algensindo

Sugiyono. (2013). Metode Penelitian Kuantitatif, Kualitatif dan R \& D. Bandung: ALFABETA.

Sundayana, R. (2016). Media dan Alat Peraga dalam Pembelajaran Matematika. Bandung: ALFABETA

Sutarti, T. \& Irawan, E. (2017). Kiat Sukses Menerima Hibah Penelitian Pengembangan. Sleman: Deepublish

Untari, E. (2013). Diagnosis Kesulitan Belajar Pokok Bahasan Pecahan pada Siswa Kelas V Sekolah Dasar. Jurnal ilmiah STKIP PGRI Ngawi, 12(2), 1-8. Retrieved from http://jurnal.stkipngawi.ac.id/index.php/mp/article/view/28/0.

Zulkardi. 2003. Pendidikan Matematika di Indonesia: Beberapa Permasalahan dan Upaya Penyelesaiannya. Palembang: Universitas Sriwijaya. 